\title{
Mid-late Holocene lake levels and trophic states of a shallow lake from the southern Pampa plain, Argentina
}

\author{
Cecilia LAPRIDA, ${ }^{1 *}$ María S. PLASTANI, ${ }^{1}$ Alicia IRURZÚN,${ }^{2}$ Claudia GOGORZA,,${ }^{2}$ Ana NAVAS,${ }^{3}$ \\ Blas VALERO-GARCÉS, ${ }^{4}$ Ana M. SINITO²
}

${ }^{1}$ Instituto de Estudios Andinos Don Pablo Groeber CONICET, Departamento de Ciencias Geológicas, Universidad de Buenos Aires, Av. Intendente Güiraldes 2160, 1428 Caba, Argentina; ${ }^{2}$ Instituto de Física Arroyo Seco, Universidad Nacional del Centro de la Provincia de Buenos Aires (UNCPBA), Pinto 399, 7000 Tandil, Argentina; ${ }^{3}$ Instituto Experimental Aula Dei, EEAD-CSIC, Avda. Montañana 1005, 50059 Zaragoza, España; ${ }^{4}$ Instituto Pirenaico de Ecología, IPE-CSIC, Avda. Montañana 1005, 50059 Zaragoza, España

*Corresponding author: chechulaprida@gmail.com

\begin{abstract}
Changes in trophic status of the shallow Lake La Brava (southeastern Pampa plain of Argentina) are evaluated based on geochemical, biological and sedimentological data. Based on a conceptual framework, we propose that the lake level defines the water column mixing conditions, affecting internal lake processes and determining the transparency of lake water. The shift between alternative states is reconstructed for the last 4800 years. Four main lake stages have been recognized, although short term shifts characterize all stages. A turbid phytoplankton-dominated state prevailed between 4700-4500 cal yr before present (BP). Drier conditions and low lake levels pushed the lake to a clear state until 2000 cal yr BP. Afterwards the lake switched back to a turbid state, and these conditions persisted until 200 cal yr BP. In the last 200 years, the lake switched back and forth between clear and turbid states. The latter represents the modern conditions of the lake since $\sim 1950$ AD. These shifts can be attributed mainly to climatic drivers.
\end{abstract}

Key words: Mid-late Holocene, paleolimnology, trophic states, southern Pampas, Argentina.

Received: July 2013. Accepted: January 2014.

\section{INTRODUCTION}

The Pampa plain is a vast grassy plain that covers central Argentina, characterized by a uniform relief except for the existence of two low altitude ranges situated toward the southeast, Tandilia (maximum height $\sim 500 \mathrm{~m}$ asl) and Ventania (maximum height $\sim 1200 \mathrm{~m}$ asl). Lakes in the pampas are small $(<50 \mathrm{ha})$ and shallow $(<10 \mathrm{~m}$ depth) and range from meso-eutrophic to hypereutrophic (Quirós et al., 2002; Quirós, 2004). They can be classified as turbid or clear according to water transparency (Quirós et al., 2002; Sosnosvky et al., 2010). These states are generally considered to be a function of their nutrient status (Scheffer et al., 1993), intrinsic processes (i.e., the effect of algae and macrophytes on nutrient dynamics, Van Nes et al., 2007), climate, and lake depth (Scheffer and Carpenter, 2003; Scheffer and Van Nes, 2007; O'Farrell et al., 2011). According to Quirós et al. (2002), the pristine state of small pampean lakes was clear, and most of them became turbid as a consequence of the expansion of the agriculture frontiers. Stutz et al. (2012) explored successfully alternative states in shallow pampean lakes in centennial time-scales and provided evidence of changes in trophic states and shift between turbid and clear since 1000 yr BP.

Few studies have inferred the environmental history of shallow lakes in the southern Pampa plain during the Holocene (Stutz et al., 2002, 2006, 2010, 2012; Borel et al., 2003; Fontana, 2005; Laprida et al., 2009, Laprida and Valero Garcés, 2009). One of these studies has reconstructed the water level of Lake La Brava over the past 4800 years based on rock magnetic, pollen, and geochemical analysis suggesting periodic climatic changes from cooler to warmer and humid conditions (Irurzún et al., in press). According to shallow lake theory, changes in turbidity depend strongly on lake depth (van Nes et al., 2002, Scheffer et al., 1993; Scheffer and van Nes, 2007). Thus, some in-lake processes related with turbidity (such as bottom redox conditions, and organic matter and calcite preservation) can be used as proxies to interpret paleolimnological records. We analyze here a multiproxy record of moisture availability and sediment redox conditions to reconstruct the trophic states of Lake La Brava since the mid-late Holocene. Lake La Brava is of special interest because functioning is well known, and it is sufficiently deep to have never gone dry since the mid-late Holocene. We demonstrate that shifts between alternative states have occurred in the last 4800 years without human-induced changes in external nutrient loading. The conceptual ecological model proposed in this paper indicates how climate affects geochemical and physical properties causing a change in the trophic state and defining the alternative 
state in the long term. Since the lakes of the Pampas are considered a common pool resources used for recreational, residential, touristic and intensive agricultural activities (Romanelli et al., 2011), knowledge of past trophic states and the understanding of its dynamics can help to decision-making and planning to define restoration and conservation efforts.

\section{GEOGRAPHICAL SETTINGS}

\section{Lake La Brava}

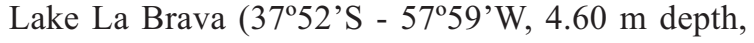
$68.03 \mathrm{~m}$ asl, Fig. 1) is located at the toe of La Brava Hill (275 m asl), in the Tandilia Range, southeastern Pampa plain (Romanelli et al., 2010b). The lake area is $4.0 \mathrm{~km}^{2}$ and has a catchment of $53.6 \mathrm{~km}^{2}$ (Romanelli et al., 2010a). The hydrogeological bedrock is covered by a loessic sequence of Pleistocene-Holocene age (Muhs and Zarate, 2001) that constitutes the Pampeano Aquifer (Sala, 1975). Analysis of eolian sediments indicated an absolute predominance of illite (Camilión et al., 1993). The formation of well-drained soils promotes significant $\mathrm{Ca}, \mathrm{Na}$ and $\mathrm{Mg}$ losses from plagioclases and volcanic glass shards, but only minor loss of K and Fe (Arens, 1969). The Pampean Aquifer in the area is unconfined with a mean electric conductivity of $\sim 830 \mu \mathrm{S} / \mathrm{cm}$ and $\mathrm{pH} \sim 7.9$. Na, Mg and bicarbonate are the dominant ions (Romanelli et al., 2011). Aquifer system recharge depends solely on rainwater infiltration mainly throughout June and October.

\section{Climate}

SE Pacific and SW Atlantic semi-permanent anticyclones $\left(\sim 30^{\circ} \mathrm{S}\right)$ dominate the southern South America circulation. South of $40^{\circ} \mathrm{S}$, low-level westerly flow prevails year round over the continent. The westerly winds are strongest during austral summer (JFM), peaking between $45^{\circ}-55^{\circ} \mathrm{S}$. During the austral winter (JJA), the axis of the jet stream moves into subtropical latitudes at about $30^{\circ} \mathrm{S}$ and the low-level westerlies expand equatorward (Garreaud et al., 2009).

The climate in the studied area is temperate humid to sub-humid with a mean annual temperature of $14.1^{\circ} \mathrm{C}$, a mean annual precipitation of $908.7 \mathrm{~mm}$ (period 19852008), and a potential evapotranspiration of $732 \mathrm{~mm}$ for the period 1985-2007 (Romanelli et al., 2010b). Winds influenced by the subtropical anticyclones combined with
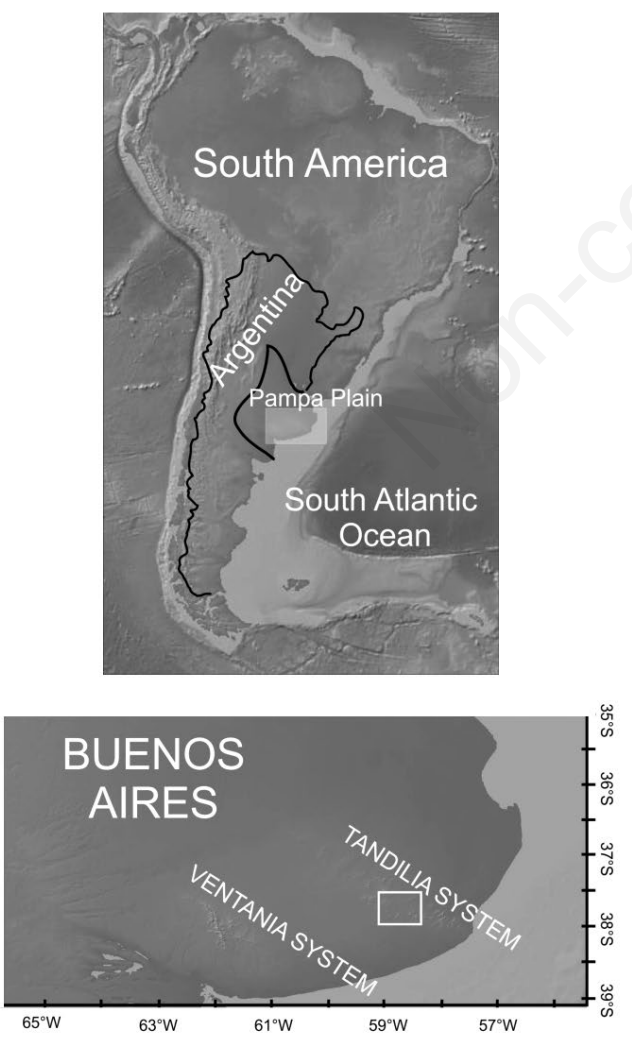

Fig. 1. Lake La Brava location map showing the studied site. Black star points out core location. Dashed white line indicates the border of the catchment basin. 
the mid-latitude westerly circulation result in a general NE-SW circulation pattern. The dry season extends from May to September, and the rainy season is from October to April (Scian et al., 2006). The intense convective activity originated in tropical regions is mainly responsible for the rainy conditions (Labraga et al., 2002; Barrucand et al., 2007). During the austral summer, a very deep continental low is formed over the Chaco region $\left(\sim 25^{\circ} \mathrm{S}\right)$ and forces the easterly winds over the Amazon basin to turn southward, transporting large amounts of moisture that feeds convective storms over the Pampa Plain as far south as $35^{\circ} \mathrm{S}$ (Garreaud et al., 2009). The winter is considered the dry season, and precipitation is principally associated with frontal systems originating from the south (Barrucand et al., 2007).

\section{Hydrology}

Lake La Brava (Fig. 1) is one of the few permanent freshwater lakes of the Pampa plain (Dangavs, 2005a). Basin morphology is relatively simple with only one influent, El Peligro stream located in the highest sector of the basin, and one effluent, the Tajamar stream. The former is a poorly sorted, sandy gravel-bed stream (Tietze and De Francesco, 2010) with permanent regime; the latter dries up during dry periods and droughts.

The hydrology is highly dependent on in situ rainfall (Quirós et al., 2006). Lake water mean annual temperature is $\sim 19^{\circ} \mathrm{C}$, mean electric conductivity is $650 \mu \mathrm{S} \mathrm{cm}{ }^{-1}$ and $\mathrm{pH}$ is $\sim 9$.1. Major ions of lake water are $\mathrm{Na}>\mathrm{Mg} \approx \mathrm{Ca}$ and $\mathrm{HCO}_{3}>\mathrm{Cl}>\mathrm{SO}_{4}$ (Tietze and De Francesco, 2010; Romanelli et al., 2010). The low salinity suggests that the residence time of water in the lake is brief. Profiles indicate that $\mathrm{pH}$ decreases with water depth at around 8.50 at 4 meters depth. Lake La Brava is polymictic, except for short periods during summer, when thermal stratification $\left(\leq 4^{\circ} \mathrm{C}\right)$ occasionally occurs. The lake is predominantly turbid (Tietze and De Francesco, 2012), but transparency is rather variable (Secchi disk transparency ranging from 0.10 to $1.4 \mathrm{~m}$; Quirós, 1988; Tietze and De Francesco, 2012). Approximately $80 \%$ of the coastline is covered by the giant bulrush Schoenoplectus californicus (Romanelli et al., 2011). Submerged plant community in the photic zone $(<2 \mathrm{~m})$ is characterized by Myriophyllum elatinoides, Ludwigia repens and Ceratophyllum demersum, while at the lake margins Azolla filiculoides, Potamogeton pectinatus, Ricciocarpus natans and Lemna sp. are present (Cordini, 1942; Irurzún et al., in press).

The hydrogeological model of Lake La Brava proposes an effluent-influent behavior in relation to both streams and groundwater (Kruse, 1987, Romanelli et al., 2010, 2011). The lake receives water and specially solutes from groundwater inflow in the higher topographic zones, and in turn discharges their waters into the aquifer in the lower ones. The presence of intermittent springs in the surrounding hills allows inferring rainwater circulation through fissure system contained within the outcropping quartzite of the hills (Tapia, 1937). Direct and indirect wetland recharge from the rain-fed springs occurs in contact with the range via surface and subsurface runoff especially in the west side of the lake, where lower conductivity of $569 \mu \mathrm{S} \mathrm{cm}{ }^{-1}$ was detected (Romanelli et al., 2010b). According to Romanelli et al. (2011), groundwater and spring water sources contribute in similar proportions to the lake.

\section{METHODS}

Fieldwork at Lake La Brava was carried out in 2002. The selection of the coring site was based exclusively on bathymetry; the deepest depocenter was selected for coring (Lirio et al., 2007). This site is far enough from El Peligro stream. Core LBr-4 (total length of $551 \mathrm{~cm}$ ) was recovered from a water depth of $3.4 \mathrm{~m}$. Coring was carried out from a platform using a push corer system equipped with 2 meter-length PVC liners of $6 \mathrm{~cm}$ diameter. A very compact dark horizon at $551 \mathrm{~cm}$ depth prevented further penetration of the corer. In the laboratory, the core was cut into $1 \mathrm{~m}$-segments and split lengthwise into halves. They were then sealed in polythene and stored in the dark at $4^{\circ} \mathrm{C}$ until further processing.

Core description was carried out immediately after core opening. One of the cores half was subsampled at 2.5 $\mathrm{cm}$ intervals. These subsamples were then split into two aliquots of $6 \mathrm{cc}$. An aliquot was used for basic geochemical and granulometric analysis. Concentrations (weightweight \%) of total sulphur (TS), total carbon (TC) and total organic carbon (TOC) were measured by using a Leco elemental analyzer at the Instituto Pirenaico de Ecología, Zaragoza, Spain. Concentration of total inorganic carbon (TIC) was obtained from the difference between TC and TOC. These parameters were used to estimate trophic state and organic matter and carbonate preservation. A set of 42 selected samples at $10 \mathrm{~cm}$-interval was analyzed for $\mathrm{Ca}, \mathrm{K}$ and $\mathrm{Fe}$ content. Content is expressed in $\mathrm{mg} / \mathrm{kg}$. Ca was used to calculate the carbonate content, to ensure that TIC originates completely from $\mathrm{CaCO}_{3}$, whereas $\mathrm{K}$ and $\mathrm{Fe}$ were used to estimate eolian influx to the lake. Analyses were performed at the Instituto Experimental Aula Dei by optic emission spectrometry using inductively coupled plasma (solid state detector). Concentrations were obtained after three measurements per element. TOC/TS weight-weight $\%$ ratio was calculated as a qualitative proxy of the redox status of the environment of deposition and salinity. Analyses of the clay, silt and sand fractions were performed using laser equipment at the Instituto Experimental Aula Dei, Zaragoza, Spain. To eliminate the organic matter, samples were chemically disaggregated with $10 \% \mathrm{H}_{2} \mathrm{O}_{2}$ heated at $80^{\circ} \mathrm{C}$, then stirred. Ultrasound was also used to facilitate 
particle dispersion Statistical correlation between all variables was calculated by means the Pearson's Correlation coefficient using PAST 2.17 software (Hammer et al., 2001). Correlations were considered significant when $\mathrm{r}>[0.5]$ and $\mathrm{P}<0.05$. As autocorrelation can complicate the identification of significant covariance or correlation between time series (Dawdy and Matalas, 1964), the temporal structure of each variable was assessed by means of one-step lagged scatterplots, fitting the data to a linear model (results not shown). Dispersion patterns were randomly structured $\left(\mathrm{R}^{2}<0.1\right.$ in all cases), therefore $\mathrm{P}$-values of the subsequent correlation analyses performed were deemed to be accurate.

Additionally, samples were treated with standard micropaleontological methods for ostracods in the Laboratorio de Sondeos Continentales y Marinos (SACMa), Buenos Aires, Argentina. Ostracods were used to estimate some paleoecological parameters as well as carbonate dissolution. Fresh sediment was washed into a $75-\mu \mathrm{m}$ porediameter sieve and dried up in a thermostatic stove at $40^{\circ} \mathrm{C}$. Agglutinated samples were treated with $10 \% \mathrm{H}_{2} \mathrm{O}_{2}$ overnight in order to facilitate the sieving by getting rid of organic matter. Five grams of sediment were examined under stereomicroscope and all ostracod valves and carapaces were picked out with a brush and placed in micropaleontological slides. Adult and juvenile ostracods were determined at species level based on Laprida (2006). The number of valves was calculated considering total number of valves (adults+juveniles) per gram of fresh sediment. Adult $v s$. juvenile ratio was used to infer taphonomic processes. Additionally charophyte oogonia, pondweed

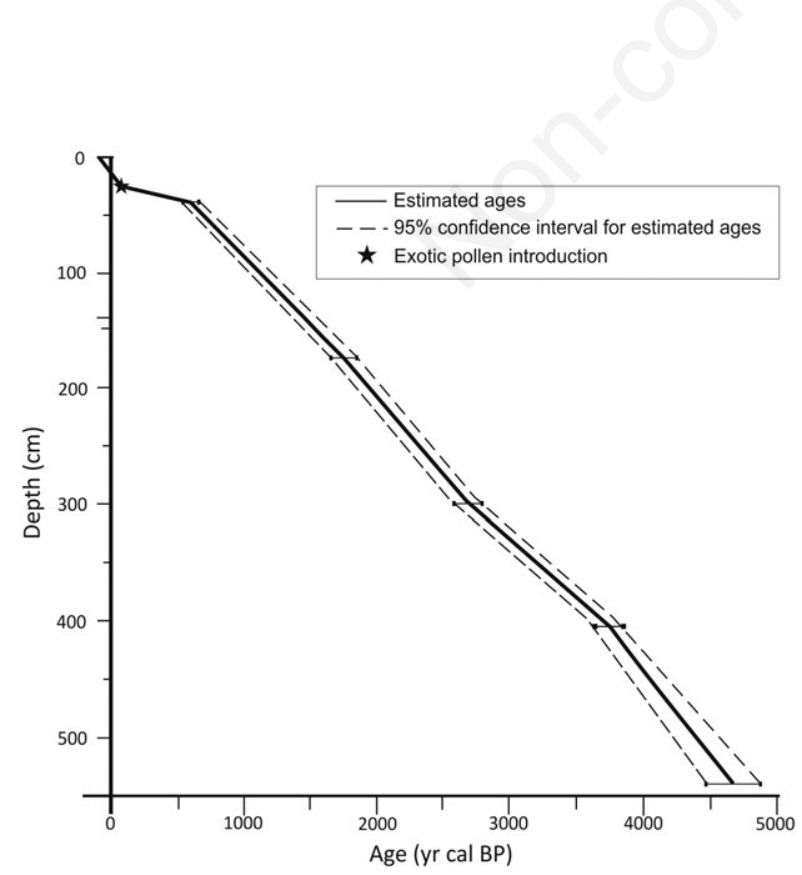

Fig. 2. Age model for $\mathrm{LBr}-4$ sediment core based on dated samples and historical data. Error bars $( \pm 2 \sigma)$ are shown. seeds, diatoms and thecamoebians have been picked out in order to reconstruct water transparency, nutrient status and habitability of bottom waters, although no quantitative analyses were performed.

A chronology based on 5 radiocarbon dates and historical data was proposed by Irurzún et al. (in press). Radiocarbon dating on bulk sediment samples were carried out by accelerator mass spectrometry (AMS) at Centro di Datazione e Diagnostica (CEDAD), Dipartimento di Ingegneria dell'Innovazione, Università degli Studi di Lecce, Italy. The Oxcal 4.1 calibration software (Bronk Ramsey, 2001, 2008) and the SHCal04 dataset (McCormac et al., 2004) were used for conversion of the conventional radiocarbon ages into calendar age (yr cal BP). Additionally, the first appearance of introduced pollen taxa at $27.5 \mathrm{~cm}$ marks the onset of human impact at the end of the $19^{\text {th }}$ century, and age assigned to this sample is $50 \mathrm{yr}$ cal BP (Irurzún et al., in press). The age model was established considering a simple linear interpolation between contiguous calibrated ages (Fig. 2).

\section{RESULTS}

The stratigraphic distribution of bioproxies is irregular along the core (Fig. 3). Ostracods show a positive correlation with carbonate concentration, since they are present exclusively in sediment where TIC concentration is higher than $1 \%$. Over 15,000 valves and carapaces were picked out from the 67 fertile samples. Complete populations (adults and juveniles in several life stages) were recovered from most samples. Fertile samples were concentrated between $518 \mathrm{~cm}$ and $217 \mathrm{~cm}$. Higher abundances $(>50$ valves/g and up to 1450 valves/g in some levels) were found between $473-457 \mathrm{~cm}, 436-415.5 \mathrm{~cm}, 390-360 \mathrm{~cm}$, and 305-279 cm (Fig. 3). In contrast, between $269 \mathrm{~cm}$ and the top, ostracods were almost completely absent. Juveniles were relative well preserved between $483-376 \mathrm{~cm}$, but most of the samples were exclusively conformed by adults, especially between $530-493.4 \mathrm{~cm}, 370.5-314 \mathrm{~cm}$, and above $279 \mathrm{~cm}$ (Fig. 3). Juveniles are more abundant in a few number of samples, and therefore adult-juvenile ratio is usually higher than 0.5 . Carapaces are subordinated, although in some samples can be relatively abundant especially between $475.5-467.5 \mathrm{~cm}, 378.5-363 \mathrm{~cm}$, $308-303 \mathrm{~cm}$ and $287-282 \mathrm{~cm}$ (Fig. 3), indicating small inlake transport of fossil remains. In some levels valves are broken, weakened (especially those of the smooth genus Heterocypris) or bored, indicating carbonate dissolution.

Five species were identified: Limnocythere cusminskyae (Ramón Mercau et al.), Heterocypris similis (Wierzejski), Heterocypris incongruens (Ramdohr), Cypridopsis vidua (Müller) and Chlamydotheca incisa (Claus). Limnocythere cusminskyae dominates and often constitutes more than $80 \%$ of the assemblages, representing as a whole $94 \%$ of individuals along the core. In fact, 25 of the 67 assem- 
blages recovered are monospecific populations of Limnocythere cusminskyae. This species is highly sexually dimorphic, populations are clearly female-dominated (female: male ratio $=4$ ). The low diversity is also reflected in the number of species per sample, which reaches at most three. Therefore, in our interpretation, we concentrate on the presence/absence of valves and species occurrence rather than on changes of their relative abundances. Heterocypris similis is the second species in occurrence, with higher relative contribution at $473.5-457 \mathrm{~cm}, 390 \mathrm{~cm}$ and $290-284.5 \mathrm{~cm}$. In the upper part of the core, Heterocypris similis is the solely species found at $91.5 \mathrm{~cm}$, although only two valves were recovered. Heterocypris incongruens, Cypridopsis vidua and Chlamydotheca incisa appeared to be very rare, and isolated individuals occurred only in a few samples (Fig. 3). Diatoms and pondweed seeds were randomly observed along the core, whereas non-calcified charophytes are restricted to the uppermost $179.5 \mathrm{~cm}$, and thecamoebians were recognized only at $173.5 \mathrm{~cm}$ and 137 cm (Fig. 3). Vertical profiles of chemical properties and grain size distribution are shown in Fig. 4. Fe correlates well with $\mathrm{K}\left(\mathrm{r}=0.66 / \mathrm{P}=1.45 * 10^{-3}\right)$ and $\mathrm{Ca}$ correlates well

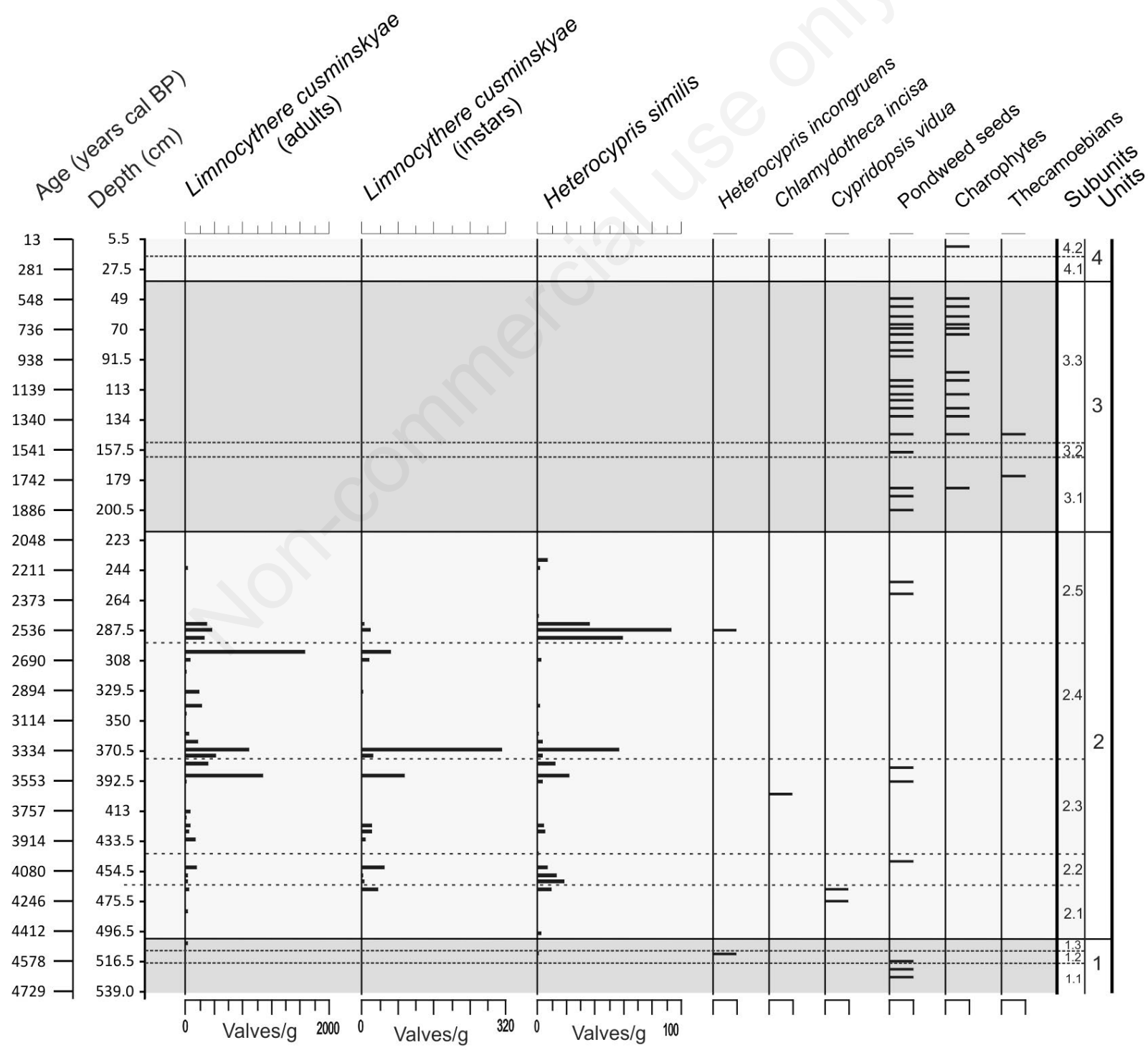

Fig. 3. Bioproxies (ostracods, pondweed seeds, charophytes and thecamoebians) from core LBr-4, Lake La Brava. Number of ostracod valves within a gram of sediment. The black bar in pondweed seeds and charophytes represents presence. Shaded areas represent major units defined based on analyzed proxies (see text for further details). 
with TIC $\left(\mathrm{r}=0.73 / \mathrm{P}=2.95 * 10^{-4}\right)$. The grain-size distribution is clearly dominated by silt, but subtle changes in clay and sand proportions are noted.

Four major units were recognized according to grainsize measurements, ostracods, pondweed seed and charophyte presence, TOC, TIC and TS contents and $\mathrm{TOC} / \mathrm{TS}$ ratio.

Unit $1(548-504.5 \mathrm{~cm})$ is characterized by fine-grained sediments, mainly clayed silt with minor proportion of sand. A distinctive basal black layer suggests high proportion of organic matter, confirmed by high content of TOC $(9.3 \%$ in average, maximum of $12.3 \%)$. TS correlates strongly with TOC $\left(\mathrm{r}=0.94 / \mathrm{P}=4.95 * 10^{-3}\right)$ indicating that TS derives mainly from organic matter. Both TOC and TS have two broad maxima at $536-530 \mathrm{~cm}(23.3-16.48 \%$ and 1.5 $0.94 \%$, respectively), and at $509 \mathrm{~cm}(15.47$ and $1.3 \%$, respectively). In contrast, TIC, Ca and Fe content are very low. The TOC/TS ratio is relatively low throughout the unit. Variations in TOC, TS and TIC values form the subdivision of Unit 1. Basal Subunit 1.1 (552-518.5 cm; Fig. 4) shows maximal values of TOC and TS, while TIC and Ca contents are negligible. Both $\mathrm{Fe}$ and $\mathrm{K}$ concentrations are relatively low, and ostracods are very scarce. Subunit 1.2 (516.5$511.5 \mathrm{~cm}$; Fig. 4) is characterized by a sudden lowering in both TOC (mean $4.56 \%$ ) and TS (mean $0.17 \%$ ). TOC/TS (mean 18.3) and TIC (mean 0.63\%) increase whereas sand is negligible. Similar patterns of TOC and TS suggest that
TS derives mainly from organic matter, but TS does not correlate with TOC, demonstrating that changes in the oxygen of the bottom waters had probably occurred. Abundant pondweed seeds were recovered. Ostracods are scarce $(<47$ individuals/g), Limnocythere cusminskyae dominates assemblages (Fig. 3). A very sharp peak at $509 \mathrm{~cm}$ on both TOC and TS marks the onset of the Subunit 1.3 (509-504 cm; Fig. 4), but peaks are not as great as the ones in Subunit 1.1. Ostracods are very scarce $(<14$ individuals/g). Both Limnocythere cusminskyae and Heterocypris similis were found (Fig. 3).

Unit $2(501.5-220.5 \mathrm{~cm})$ is characterized by generally smaller, but significantly fluctuating, grain size distribution and lower organic matter content as indicate TOC and TS contents; and higher but significantly fluctuating TIC (mean $1.05 \%$ ) and TOC/TS (mean 26.66) (Fig. 4). Ca reaches maximum concentrations $(57.749 \mathrm{mg} / \mathrm{kg})$ at $444 \mathrm{~cm}$. TS and TIC correlate with TOC $\left(\mathrm{r}=0.57 / \mathrm{P}=1.25 * 10^{-10}\right.$ and $\mathrm{r}=0.64 / \mathrm{P}=$ $3.15_{*} 10^{-14}$ respectively). Fe and $\mathrm{K}$ increase gradually reaching maximum concentrations upwards (Fig. 4). Ostracods are abundant (up to 15,000 individuals/g in some levels; Fig. 3). A marked decrease in TS (mean $0.23 \%$ ) marks the onset of the Subunit $2.1(501.5-467.5 \mathrm{~cm})$. A decrease in TOC (mean $4.17 \%$ ) also occurs, and high TOC/TS ratio correlates negatively with TS content $\left(\mathrm{r}=-0.79 / \mathrm{P}=7 * 10^{-4}\right)$ (Fig. 4). TS diminish abruptly at $501.5 \mathrm{~cm}$, while TOC and TOC/TS ratio increase. Relatively low values of TIC and

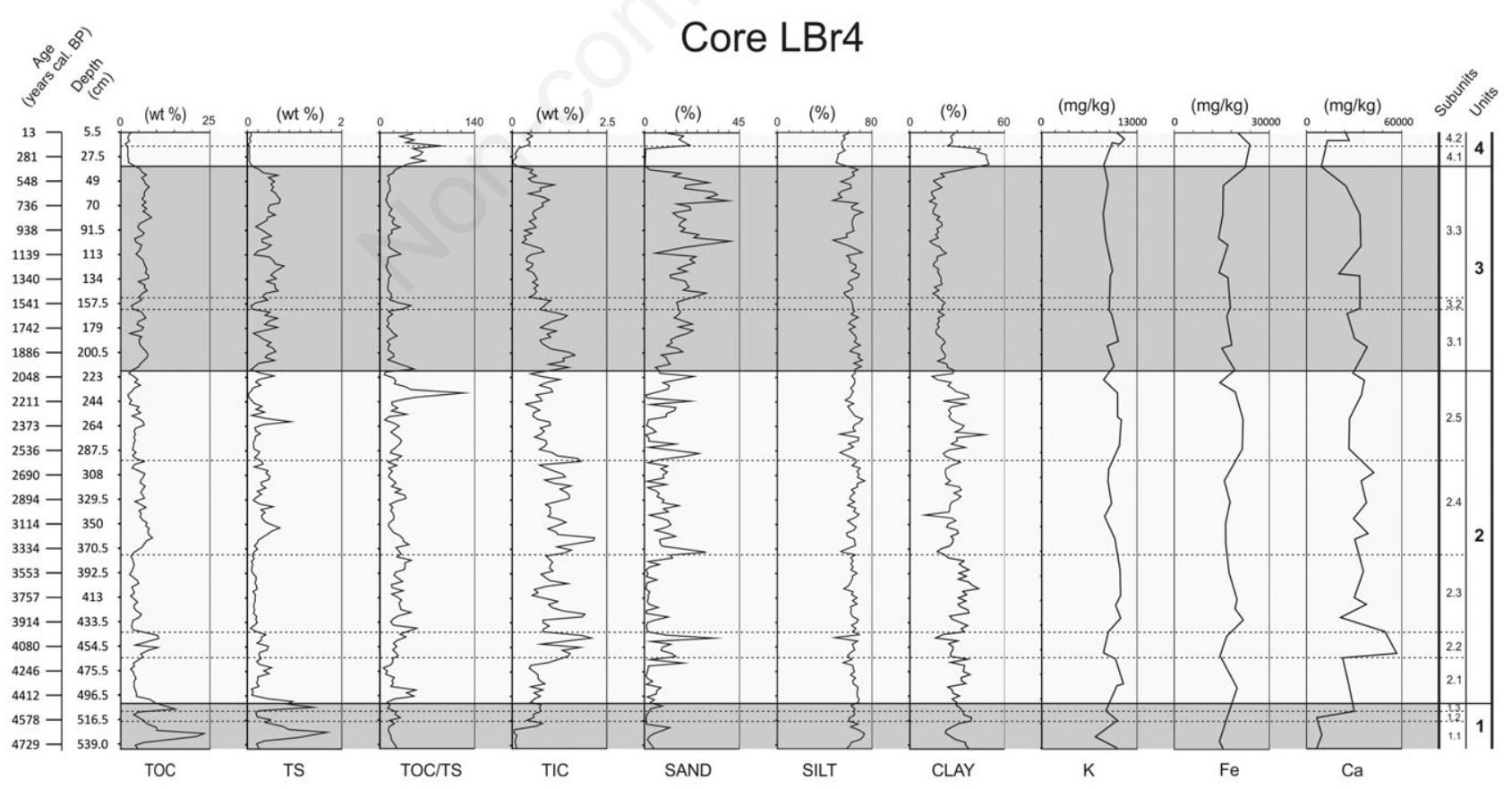

Fig. 4. Geochemical and sedimentological proxies from the core LBr-4. Total organic carbon (TOC), total sulphur (TS), TOC/TS relationship, total inorganic carbon (TIC), sand, silt, clay, potassium (K), iron (Fe) and calcium (Ca). Shaded areas represent major units defined based on analyzed proxies (see text for further details). 
TOC/TS occur towards the top of the subunit showing their minimum at $475.5 \mathrm{~cm}(0.43 \%$ and 5.8 , respectively). In Subunit 2.2 (465.5-444 cm, Fig. 4), TOC and TIC increase significantly and correlate $\left(\mathrm{r}=0.82 / \mathrm{P}=6.72 * 10^{-3}\right)$. There is a gradual increase in TOC/TS values upwards, where sand reaches $35 \%$. Conversely, $\mathrm{Fe}$ and $\mathrm{K}$ concentrations reach their minimum $(15.307 \mathrm{mg} / \mathrm{kg}$ and $8726 \mathrm{mg} / \mathrm{kg}$, respectively). TS correlates with TOC ( $\mathrm{r}=0.71 / \mathrm{P}=0.03)$. The presence of small gypsum rosettes at $452 \mathrm{~cm}$ is coincident with a peak in TIC. Amount of finely dispersed organic material is low in Subunit 2.3 (441.5-378 cm; Fig. 4), as indicated by low TOC and TS values. TOC/TS ratio increases when TOC and TS decrease. TIC concentration is low but fluctuating (1.06\% in average) while $\mathrm{K}$ and $\mathrm{Fe}$ increase. TS strongly anticorrelates with TOC/TS $(r=-0.78 / \mathrm{P}=3.83$ * $\left.10^{-6}\right)$, and TOC and TIC show a strong positive correlation $\left(\mathrm{r}=0.82 / \mathrm{P}=4.66 * 10^{-7}\right)$. In Subunit $2.4(376-298 \mathrm{~cm}$; Fig. 4), TOC and TS correlate $\left(\mathrm{r}=0.57 / \mathrm{P}=8.03 * 10^{-4}\right)$. TIC reaches higher values $(1.25 \%)$, and correlates moderately well with TOC $\left(\mathrm{r}=0.5 / \mathrm{P}=8 \cdot 9 * 10^{-3}\right)$. TOC/TS is generally low and significantly fluctuating, and strongly anticorrelates with TS $\left(\mathrm{r}=-0.80 / \mathrm{P}=6.45_{*} 10^{-8}\right)$. Gypsum rosettes were found at 355 $\mathrm{cm}$, consistent with a peak in TS $(0.62 \%)$, although Ca decreases. $\mathrm{K}$ and Fe decrease gradually toward the top of the subunit. Variable proportion of sand indicates fluctuating clastic input to the lake. Subunit 2.5 (295-220.5 cm, Fig. 4) is characterized by a lowering in TIC $(0.82 \%)$, and low but significantly fluctuating organic matter, as indicated by TOC and TS values. TOC and TS correlate well $(r=0.64 / \mathrm{P}=$ $\left.1.46 * 10^{-4}\right)$. A very sharp peak of TS $(0.98 \%)$ coincides with minor proportion of sand, and low TOC/TS ratio (7.06) at $261.5 \mathrm{~cm}$. K and Fe concentrations increase, whereas Ca decrease. The TOC/TS ratio anticorrelates with TS $(r=$ $\left.-0.54 / \mathrm{P}=2.2^{*} 10^{-3}\right)$ and displays a broad and distinct peak at $238 \mathrm{~cm}$, in coincidence with a minimum in TS $(0.01 \%)$.

Unit $3(217-38.5 \mathrm{~cm})$ is characterized by a distinctive increase in sand, TOC and TS, whereas TOC/TS ratio (20.52 in average) is relatively low (Fig. 4). TOC and TOC/TS correlate strongly with TS $\left(\mathrm{r}=0.74 / \mathrm{P}=3.2 * 10^{-13}\right.$ and $\mathrm{r}=-0.82 / \mathrm{P}=5.4_{*} 10^{-18}$, respectively). Although silt is dominant, sand increases notably upwards. Very scarce ostracods ( $<11$ individuals/g) belonging to Limnocythere cusminskyae were found, although non-calcified charophyte oogonia and pondweed seeds are frequent in almost all levels (Fig. 3). K and Fe decrease. A strong decrease in TOC, TS and TIC between 163-149.5 cm support the subdivision in three subunits. Subunit 3.1 (217-166 cm; Fig. 4) is characterized by higher and well-correlated TOC and TS values $\left(\mathrm{r}=0.68 / \mathrm{P}=9.52 * 10^{-4}\right)$. TOC/TS ratio (19 in average) is relatively low and correlates strongly with TS $\left(\mathrm{r}=0.81 / \mathrm{P}=1.59 * 10^{-5}\right)$. TIC increases markedly and peaks toward the base reaching $1.67 \%$, and correlates with TOC $(r=0.55 / \mathrm{P}=0.01)$. Sand gradually increase from less than $5 \%$ at the base to more than $20 \%$ towards the top. A marked peak on TOC/TS ratio (jumping from 13.35 to 35.76 ) and a large negative excursion in TOC and TS $(4.54 \%$ and $0.22 \%$, respectively; $\left.\mathrm{r}=0.98 / \mathrm{P}=3.06 * 10^{-4}\right)$ characterize the Subunit $3.2(163$ $149.5 \mathrm{~cm}$; Fig. 4). TOC/TS ratio strongly anticorrelates with TS $\left(\mathrm{r}=-0.94 / \mathrm{P}=4.63 * 10^{-3}\right)$. No charophyte oogonia was found in this interval (Fig. 3). Subunit 3.3 (147-38.5 cm; Fig. 4) is characterized by generally higher, but significantly fluctuating organic matter, as indicated by TOC and TS (5.62\% and $0.35 \%$, respectively). TOC/TS ratio tends to be low. TS correlates with TOC $\left(\mathrm{r}=0.66 / \mathrm{P}=2.03 * 10^{-6}\right)$ and strongly anticorrelates with TOC/TS $\left(r=-0.83 / \mathrm{P}=8.28 * 10^{-12}\right)$. Sand content oscillates but increases markedly toward the top showing two conspicuous peaks ( $>40 \%)$ at $99 \mathrm{~cm}$ and $65 \mathrm{~cm}$. Charophyte oogonia and pondweed seeds are abundant (Fig. 3).

Unit 4 (topmost $33 \mathrm{~cm}$ of the core) is characterized by the lowest values of TOC and TS $(2.15 \%$ and $0.04 \%$ in average) of the entire core, and by unusually high TOC/TS ratio (51.72 in average) (Fig. 4). Maximum values of $\mathrm{Fe}$ and $\mathrm{K}$ occurred near the top of the zone, whereas TIC and Ca values decrease. Between $33 \mathrm{~cm}$ and $16 \mathrm{~cm}$ (Subunit 4.1$)$ there is a marked peak in clay $(>40 \%)$. The sand increases $(>15 \%)$ and clay decreases $(<30 \%)$ in the uppermost $16 \mathrm{~cm}$ (Subunit 4.2).

\section{DISCUSSION}

Models of lake recharge allow to infer that La Brava lake-level responds mainly to the relationship between precipitation and evaporation in the lake basin (Quirós et al., 2002; Romanelli et al., 2010a). Precipitations are more frequent during austral summer (Penalba and Bettolli, 2011), thus this is the dominant season defining lake levels in the long term. Even when wetness/dryness of warm season is the major driving force, abundant winter precipitation favors groundwater recharge while hot summers promote evaporation. Thus, under particular circumstances, cooler conditions may produce a lake-level response similar to wetter conditions.

\section{Lake La Brava hydroecological model}

The conceptual hydroecological model for Lake La Brava (Fig. 5) has been developed based on previous hydrogeological and ecological studies on Lake La Brava and other shallow pampean lakes (Quirós, 1998, 2004; Quirós et al., 2002, 2006; González Sagrario et al., 2009, Gabellone et al., 2001, Sosnovsky et al., 2010; Romanelli et al., 2010a, 2010b, 2011, O'Farrell et al., 2009, 2011; Tietze and De Francesco, 2010, 2012; Izaguirre and Vinocur, 1994; Garibotti et al., 2009; Sosnovsky and Quirós, 2006) as well as on principles of the shallow lakes theory (Scheffer et al., 1993, Scheffer and van Nes, 2007; van Nes et al., 2007). It is important to emphasize 
that this model is non-quantitative, and it has been designed to analyze the theoretical linkages between climate, lake level and in-lake processes to allow paleolimnological interpretation.

The hydroecological model contemplates three alternative scenarios. These scenarios are generalizations and represent the end-member of a continuum spectrum of possible different states. The first scenario ( $\mathrm{Sc} 1)$ considers high water level related with wetter conditions and positive moisture balance (Figs. 5A and 6). These conditions lead to a loss of submerged macrophytes, enhancing phy-
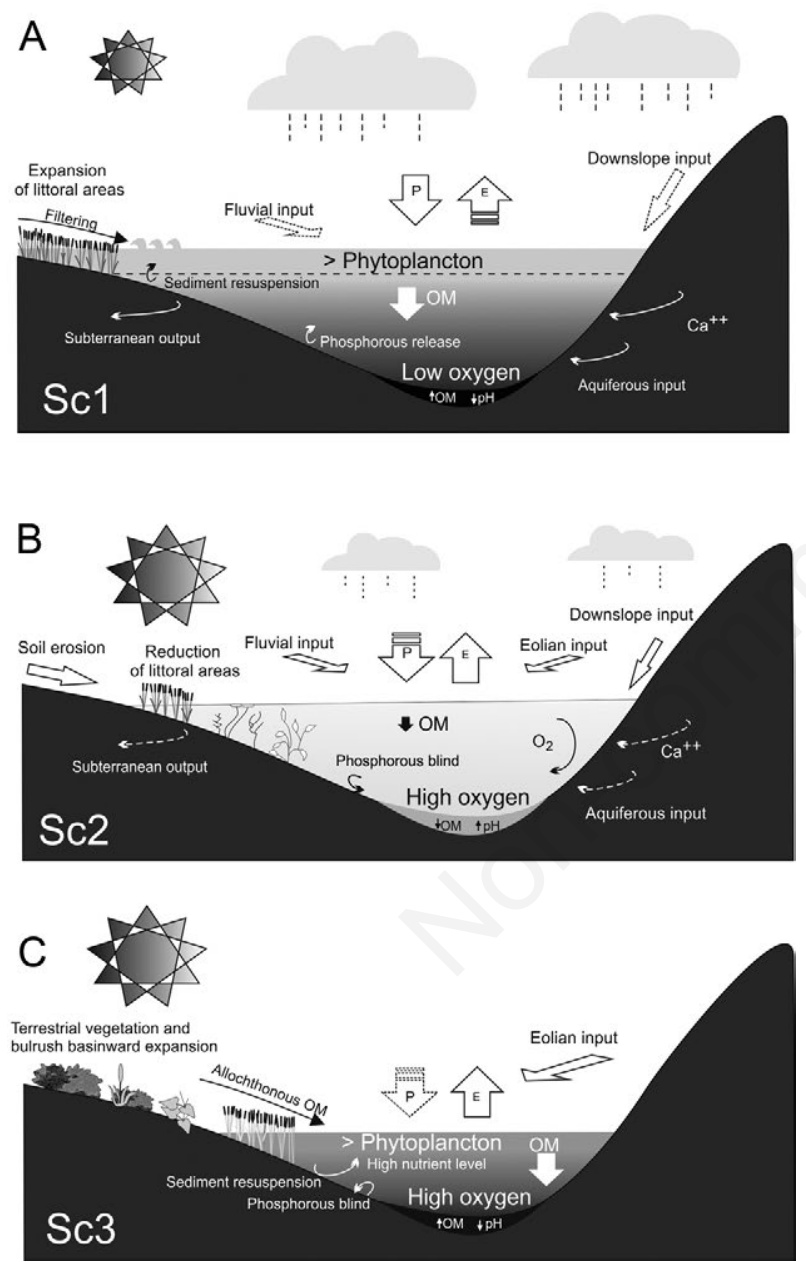

Fig. 5. Lake La Brava hydroecological model. A) When lake level is high, the positive moisture balance pushes the lake to a turbid state (Sc1, see text and Fig. 6 for further details). B) When lake level is low, the negative moisture balance pushes the lake to a clear state ( $\mathrm{Sc} 2$, see text and Fig. 7 for further details). C) During extremely negative moisture balance, droughts push the lake to a turbid inorganic stage ( $\mathrm{Sc} 3$, see text and Fig. 8 for further details). The thickness of the arrows shows intensity of processes. P, precipitation; E, evapotranspiration; OM, organic matter; $\mathrm{Ca}++$, calcium. toplankton production and stimulating a shift to a turbid, eutrophic state (Scheffer and Van Nes, 2007). High lake level favors summer stratification especially during the warm season (Mullins, 1998). Aerobic degradation of organic matter is thus limited by oxygen consumption due to secondary redox reactions (Canavan et al., 2006), inducing phosphorus release from sediments. Subsequent mixing brings a significant increase of nutrients in the whole water column. Primary and secondary redox reactions and related production of $\mathrm{CO}_{2}$ lower the $\mathrm{pH}$ in the sediments, driving carbonate dissolution (Müller et al., 2003). Wetter conditions favor clastic input from El Peligro stream but dense vegetation in the littoral areas acts as a filter, while down-slope movement of sediment derived from La Brava Hill is also reduced due to dense vegetation cover. Occasional heavy rains enhance erosion increasing allochthonous organic matter and nutrient input to the lake.

The second scenario ( $\mathrm{Sc} 2)$ considers low lake level under lower precipitation (Figs. 5B and 7). Shallow water favors mixing of the water column, and the development of submerged vegetation in the photic zone (Scheffer and Van Ness, 2007). Vegetation tends to enhance water clarity by reduction of nutrient availability and by acting as shelter for phytoplankton-grazing zooplankton (Scheffer et al., 1993). Mixing usually supplies enough oxygen to the sediment surface to maintain a superficial aerobic layer where $\mathrm{Fe}$ (II) is oxidized and precipitates with phosphorus. Because of this immobilization of nutrients, the phytoplankton primary productivity and organic carbon production drop (Scheffer, 2004). Drier conditions favor eolian activity, and thus $\mathrm{Fe}$ and $\mathrm{K}$ input increase. Aerobic degradation of organic matter is not limited by oxygen, and $\mathrm{pH}$ tends to increase. Higher alkalinity and $\mathrm{pH}$ favor carbonate precipitation (Wittkop et al., 2009) but only to the point of solute limitation of the cation, as carbonate precipitation may deplete lake Ca relative to low inflowing groundwater specially during very dry phases (Shapley et al., 2005).

The third scenario $(\mathrm{Sc} 3)$ considers lowest lake level under strong negative water balance pushing the lake to a turbid state (Figs. 5C and 8). Conductivity, nutrient concentrations, phytoplankton biomass and especially inorganic turbidity increase because of frequent sediment resuspension (Garibotti et al., 2009; Quirós et al., 2002; Izaguirre and Vinocur, 1994; Sosnovsky and Quirós, 2006). These conditions lead to a loss of submerged macrophytes, enhancing organic carbon production and accumulation (Scheffer and Van Nes, 2007). During droughts, input of allochthonous organic matter and eolian dust from extensive areas denuded of vegetation increase. Rates of carbonate formation declines dramatically, because of low rates of groundwater influx, and because of lower $\mathrm{pH}$ related with aerobic degradations of organic matter. 


\section{Paleoecological interpretation of Core $\mathbf{L B r}-4$}

Geochemical, micropaleontological and granulometric analysis of core LBr-4 allow affirming that Lake La Brava has shifted between alternatives states since the mid-late Holocene. Changes in lake level and related intrinsic processes in secular and decadal time-scales forced these shifts. Our results are in accordance with the recent hydrological balance of the lake proposed by Irurzún et al. (in press). We concentrate here in the shifts between alternative states of the ecosystem through time.

During the mid-late Holocene between 4730-4510 cal yr BP (Unit 1, Fig. 4), high content of organic matter suggests high lake levels and turbid waters consistent with the $\mathrm{Sc} 1$ proposed in the conceptual model (Fig. 5A). Deposits were formed in a high productive, eutrophic turbid lake. Strong correlation between TOC and TS suggests that sulfur derives from organic matter. TOC/TS ratio values indicate anoxic conditions arising from incomplete mixing of the water column, thus pointing to higher lake-levels and moister conditions than present. Water rising of ca. $3 \mathrm{~m}$ is indicated by prominent cliffs in north and south coasts of the lake. The enlargement of the surface area of the lake promoted the development of emergent littoral vegetation, which in turn reduced wave action favoring anoxic bottom water conditions. High lake level is also indicated by a low mean grain size. Denser vegetation in the littoral areas and the filtering of the inflow through littoral reed beds related to the high lake level diminished the sand input to the deepest parts of the lake. High lake level promoted allochthonous organic matter input because of flooding of shallow, littoral parts of the lake basin, enhancing TOC content. Maximum lake level occurred between 4730-4580 yr cal BP and 4540$4510 \mathrm{yr}$ cal BP (Subunits 1.1 and 1.3, Fig. 4) in coincidence with TOC and TS maxima and low TOC/TS ratio. Despite the absence of ostracod fossil remains, the presence of benthic diatoms belonging to Campylodiscus bicostatus (Smith), Cyclotella meneghiniana (Kützing), Surirella rorata (Frenguelli), Caloneis westii (Smith) and Epithemia

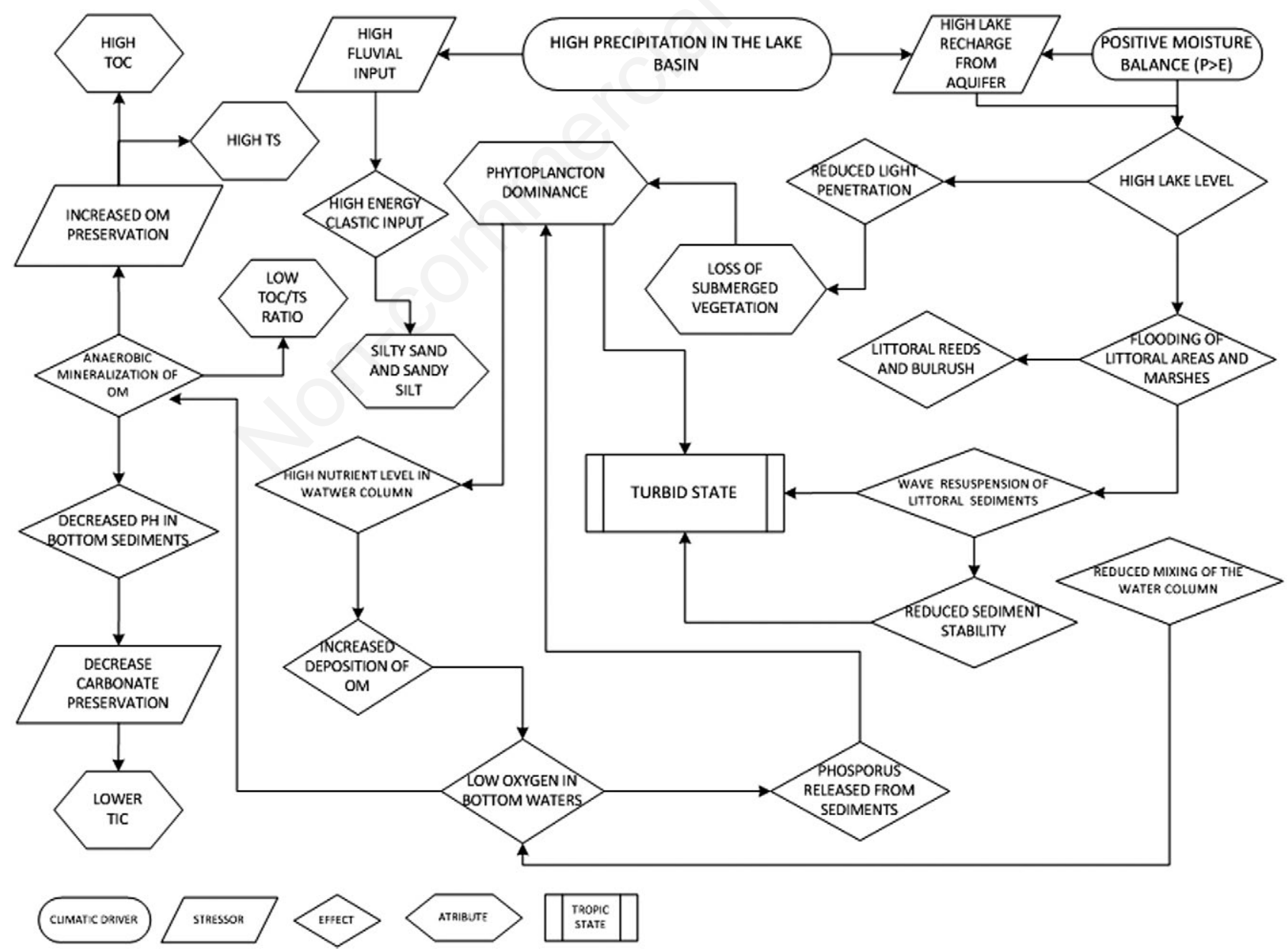

Fig. 6. Flux diagram of hydrological model from Lake La Brava considering high lake level (Sc1, see text for further details). 
adnata (Kützing) (Nora Maidana, com. pers.) (Fig. 3) indicate that oxygen depletion was limited to the deepest part of the lake. A short-term lake-level drop occurred between $4570-4560$ yr cal BP (Subunit 1.2) pushing the lake temporarily to a clear state ( $\mathrm{Sc} 2)$. The abrupt lowering of TOC and TS, and higher TOC/TS ratio (Fig. 4) indicate lower primary production or aerobic decomposition of organic matter because of enhanced mix and oxygen saturation of bottom waters. Conductivity and alkalinity increased as a consequence of the lake level drop, favoring carbonate precipitation, and preservation. The lowering of sand indicates that the lake did not receive fluvial input because of drier conditions during an otherwise humid interval.

A lake-level drop at 4490 cal yr BP represents the onset of an extended dry phase lasting more than two millennia between 4490-2030 yr cal BP (Unit 2). Increasing proportions of $\mathrm{K}$ and $\mathrm{Fe}$ imply enhanced eolian input to the lake (Fig. 4). The general lowering in productivity and enhanced bacterial decomposition of organic matter under aerobic conditions are indicated by a gradual decrease in TOC and high TOC/TS ratios (Wagner et al., 2009). From $4450 \mathrm{yr}$ cal BP to $2500 \mathrm{yr}$ cal BP, the increase in TIC co- incides with the appearance of well-preserved ostracod valves (Figs. 3 and 4). The presence of both adults and juveniles of several stages suggests that they were deposited in situ, and represent parautochthonous thanatocoenoses with little in-lake transport but strong taphonomic modifications. Scarcity of juveniles indicates selective dissolution of smallest and fragile valves in some levels (Laprida and Valero Garcés, 2009). Limnocythere cusminskyae dominates assemblages and indicates that conductivity was relatively low (total dissolved solids $<2 \mathrm{~g} \mathrm{~L}^{-1}$ ). Due to generally dry climate, reeds covered diminished, leading to a reduced filter effect and enhanced sand transport to the lake basin. However, fluctuating values of TOC/TS, TOC and TIC contents (Fig. 4) indicate that the redox condition and probably salinity were variable during this period (Cohen, 2003; Wagner et al., 2009). K, Fe and grain size distribution also suggest moisture variability, with somewhat more humid periods alternating during this generally dry interval. Low TIC, TOC and TS values and high TOC/TS ratios (Fig. 4) are consistent with a Sc2 especially between 4490-4220 (Subunit 2.1), 4020-3450 yr cal BP (Subunit 2.3), and 2620-2030 yr cal BP (Subunit

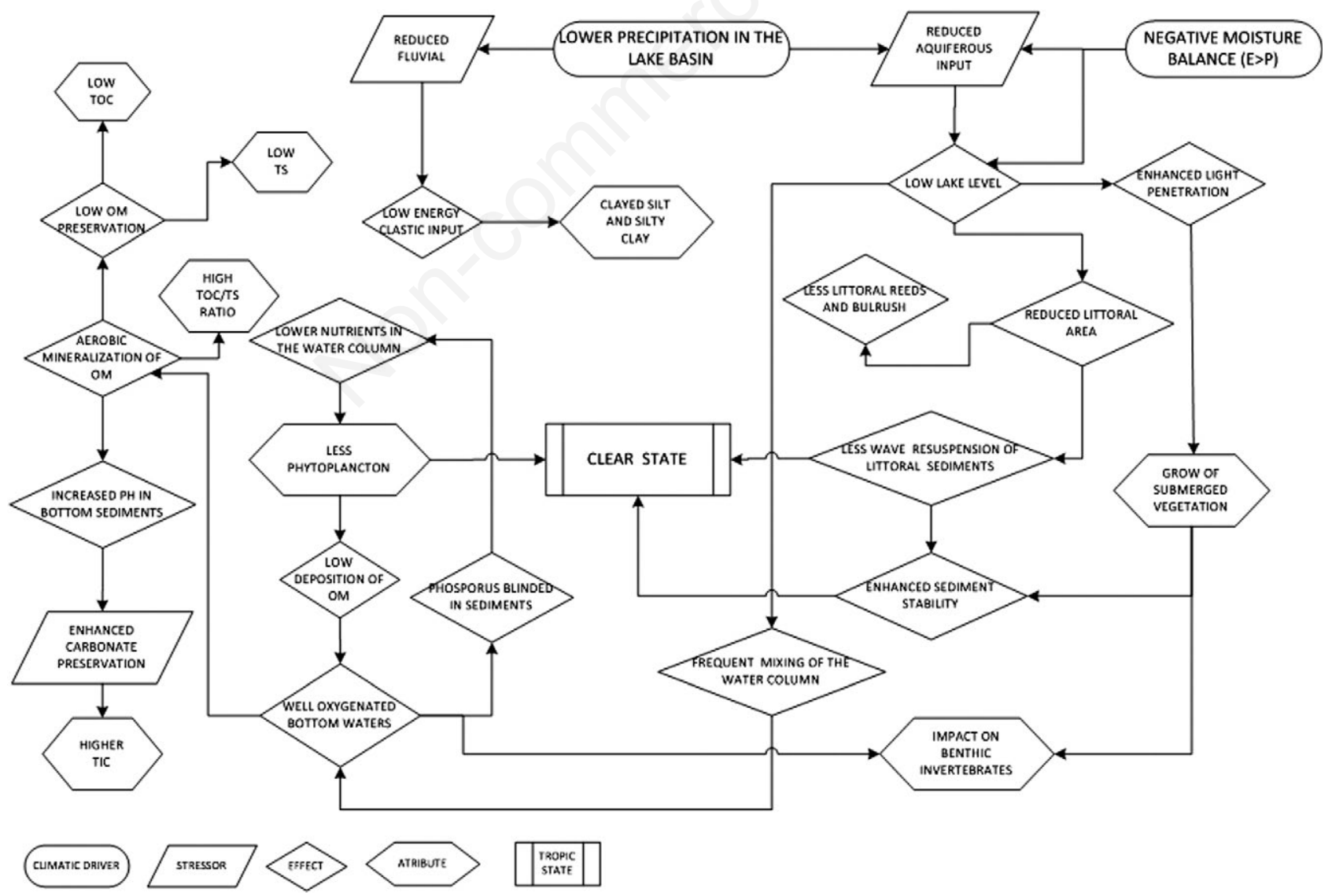

Fig. 7. Flux diagram of hydrological model from Lake La Brava considering low lake level (Sc2, see text for further details). 
2.5). Gradual decrease in TOC implies that the organic matter was affected by bacterial decomposition under aerobic conditions. The absence of pondweed seeds and noncalcified charophytes (Fig. 3) indicate that the environmental conditions (i.e., frequent inorganic turbidity related with low lake levels) did not allow the settlement of abundant submerged vegetation, except for short periods in littoral areas. Sporadic sand lenses indicate occasional heavy rains, and the presence of Heterocypris similis and Cypridopsis vidua around 4310-4230 yr cal BP and between $\sim 2600-2500 \mathrm{yr}$ cal BP (Fig. 3) indicates water exchange with temporary pools (Laprida, 2006; Laprida and Valero Garcés, 2009). From 2500 yr cal BP, sediments are devoid of carbonate (TIC $<0.5 \%$ ). A broad peak in TS suggests a relative brief but severe drought at $2350 \mathrm{yr}$ cal BP in coincidence with low sand content (Fig. 4). Pondweed seeds at $2335 \mathrm{BP}$ and $2250 \mathrm{yr}$ cal BP indicate brief episodes of well-developed littoral vegetation and quieter waters. Higher contribution of sand indicates enhanced precipitation and fluvial input between 2190 and $2150 \mathrm{yr}$ cal BP related with heavy rains in a dry context.

Between 4200-4040 yr cal BP (Subunit 2.2) and 34202640 yr cal BP (Subunit 2.4), coarse mean grain-size represents a lowering in the lake level and the progradation of the fluvial facies towards the lake basin (Fig. 3). Lower water level pushed the lake to a turbid, Sc3 state. The significant increase in TOC and TIC resulted from enhanced productivity in the lake whereas relative high TOC/TS ratios indicate well-oxygenated bottom waters, and restricted thermal stratification. Monospecific assemblages of Limnocythere cusminskyae confirm high alkaline lake waters (Fig. 3). Oscillating values of TOC, TIC and $\mathrm{TOC} / \mathrm{TS}$ indicate environmental instability. The presence of gypsum and a peak of calcite (Fig. 4) indicate a severe drought centered at $4100 \mathrm{yr}$ cal BP. Gypsum is often associated with arid conditions and it is a common endogenic mineral in some lakes of the Pampa plains (Dangavs, $2005 \mathrm{a}$ and b). A conspicuous peak of clastic sand at $\sim 3360$ BP indicates relatively high fluvial input to the lake and hence presumably greater moisture in the lake basin. The presence of Heterocypris similis between $\sim 3500-3300$ yr cal BP and higher concentrations of organic matter between 3390-3220 BP (Fig. 3) indicate water exchange with temporary pools and allochthonous sources of organic matter. A severe drought at $3200 \mathrm{yr}$ cal $\mathrm{BP}$ is indicated by the presence of gypsum rosettes and a peak in TS, not consistent with the TOC content. High TOC/TS ratio together with very low TS values indicate a lowering of the salinity in the water column and can be interpreted as a relative lake level rise at $2950 \mathrm{yr}$ cal BP

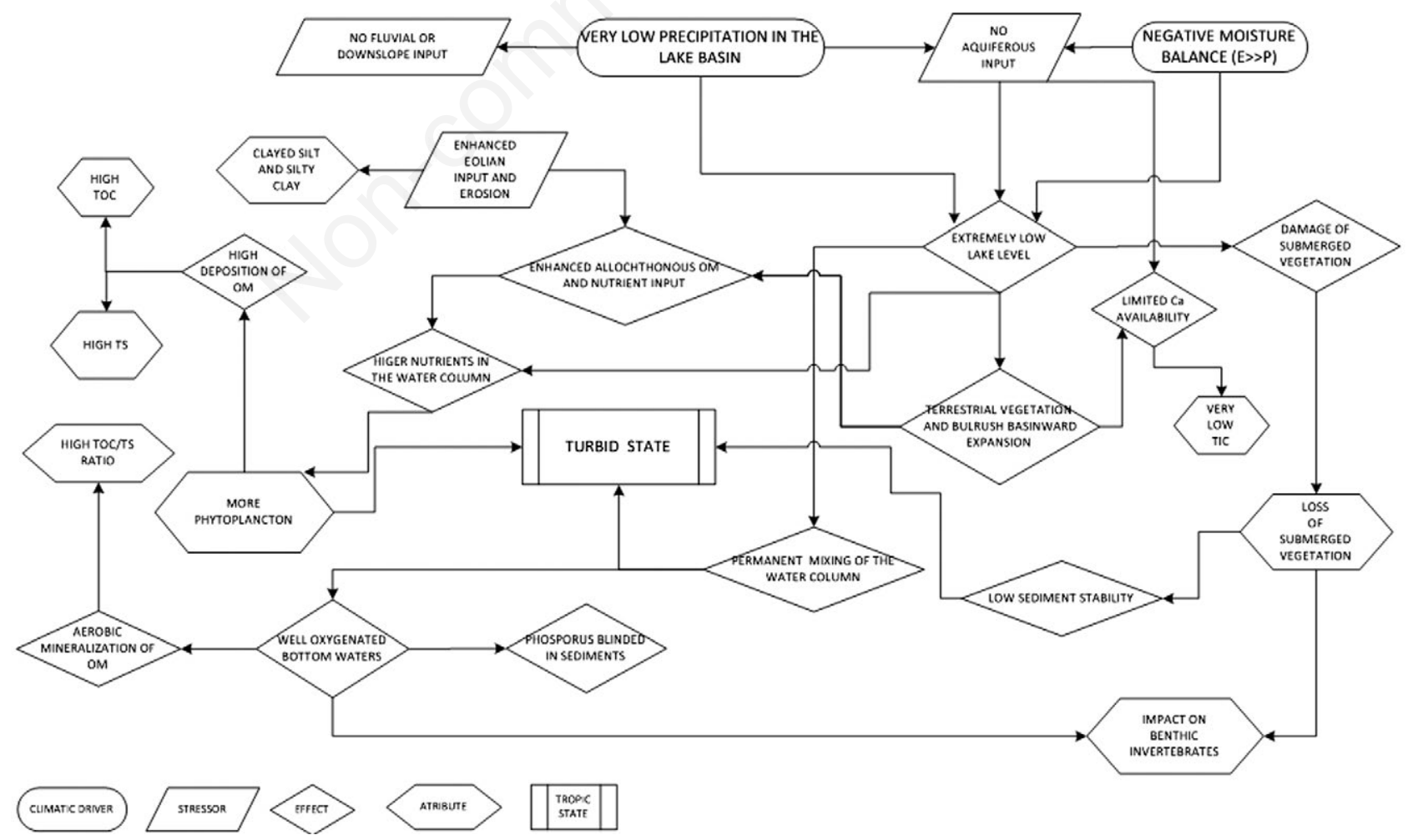

Fig. 8. Flux diagram of hydrological model from Lake La Brava considering extremely low lake level (Sc3, see text for further details). 
(Fig. 4). Increase in TOC and TS concentrations, and low values of TIC and TOC/TS at $2050 \mathrm{yr}$ cal BP imply lowering $\mathrm{pH}$ and enhanced mineralization of settled organic matter. These conditions are consistent with a lake level rise related with slightly humid climate, promoting temporary stratification of the water column at least during short periods in summer.

All the proxy data indicate high lake levels between 2010-280 yr cal BP (Unit 3) promoting a shift to a turbid, Sc1 state. Higher TOC, TS and low TOC/TS ratios (Fig. 4) indicate high primary production and preservation of organic matter especially between $2010-1595 \mathrm{yr}$ cal BP (Subunit 3.1) and 1430-280 yr cal BP (Subunit 3.3). However, lower TOC and TS values indicate that the lake level was lower than in the mid-late Holocene. Ostracods are scarce, but the presence of non-calcified charophyte oogonia and thecamoebians belonging to Centropixys marsupiformis (Wallich) and Centropixys aculeata (Ehrenberg) (Fig. 3), indicate that the absence of ostracods is linked with low $\mathrm{pH}$ of the interstitial waters. Oscillating TOC, TS and TOC/TS values indicate instable environmental conditions and probably multi-decadal humidity variations (Fig. 4). Longer phases of reduced mixing and hypolimnetic oxygen depletion disrupted by short pulses of complete mixing and oxygenated bottom waters indicate high-frequency wet/dry oscillations. Stagnation of vertical mixing may have been enhanced by steep vertical gradient of temperature due to warmer summers favoring oxygen depletion of the hypolimnion, and the preservation of organic matter in the deepest part of the lake. Abundance of pondweed seeds and non-calcified charophytes (Fig. 3) indicate limited turbidity and abundant submerged vegetation in littoral areas, relative low bicarbonate concentration and moderate salinities (Scheffer and Van Nes, 2007). The presence of Heterocypris similis indicates oligohaline salinities and well-developed submerged vegetation. Around $1600 \mathrm{yr}$ cal BP, decreasing K and Fe concentrations imply decreasing erosion in the catchment, and higher proportion of sand indicates enhanced fluvial input to the lake (Fig. 4). Coring site is not far enough from the lake margins so that the sediment composition would be likely to record a few tens of meters of basinward shoreline migration due to natural infilling of the lake (Dustin et al., 1986). Hence, increasing organic and decreasing carbonate contents may be related with migration of sedimentary environments during bench progradation and greater influence of nearshore facies than do changes in carbonate or primary production (Dustin et al., 1986). Conditions were drier between $1570-1450 \mathrm{yr}$ cal BP (Subunit 3.2). The negatives excursions in TOC and TS mark a change in productivity (Fig. 4), and TOC/TS ratios indicate enhanced mineralization of settled organic matter and fully oxygenated bottom of the lake typical of a Sc2. The marked lowering in sand indicates limited flu- vial input, consistent with a relative dry interval and related lake level drop. Thereafter $1450 \mathrm{yr}$ cal BP (Subunit 3.3, Fig. 4), wetter conditions predominated anew promoting a shift to a Sc1. However, lake-level was lower than in the previous humid phases, as low TS and high TOC/TS indicate frequent mixing of the water column and decomposition of organic matter, especially at 1130 yr cal BP and $915 \mathrm{yr}$ cal BP. Higher TOC and TS, and lower TOC/TS between 865-215 yr cal BP indicate reduced mixing and hypolimnetic oxygen depletion, probably as a consequence of an intensification of the thermal stratification (Mullins, 1998).

An abrupt environmental change took place at $215 \mathrm{yr}$ cal BP (Unit 4, Fig. 4). Low productivity is confirmed by low TS, TIC and TOC content, while high TOC/TS implies well oxygenated bottom waters. Cold, windy and dry climate probably associated with the Little Ice Age, reduced thermal stratification and favored total mixing of the water column and the shifting to a Sc2 (Subunit 4.1). The limited source of $\mathrm{Ca}$ and therefore low values and TIC resulted from an extremely low aquifer because of multi-decadal droughts. Higher values of Fe (Fig. 4) could be related to human disturbance since $1900 \mathrm{AD}$, in coincidence with the beginning of intense agricultural activities in the area (Stutz et al., 2012). Since $\sim A D 1950$ (Subunit 4.2) there is a shift to a Sc3, when enhanced productivity and thermal stratification of the lake promoted oxygen depletion. This is probably associated with higher summer temperatures and with agricultural activities, that increases the nutrient input to the lake. Irurzún et al. (in press) pointed out an increase of introduced European weeds for the last $50 \mathrm{yr}$ cal BP attributed to a decrease in grassland from livestock grazing. Sand content reflects enhanced fluvial input to the lake and littoral progradation to the core setting, although erosion processes could also have been promoted by human induced deforestation.

\section{Southern Pampas Holocene paleoclimatic reconstructions}

Paleolimnological reconstruction and shifts between alternative states of Lake La Brava agree well with previous paleoenvironmental and paleoclimatic reconstructions of southern Pampas. The mid-Holocene in the southern Pampas was generally humid (Prieto, 1996; Zárate, 1997). According to Tonello and Prieto (2010), precipitation in southeastern Pampas was higher than present between $5500-3000$ yr cal BP. The eolian activity, which was very much reduced or negligible during the generally humid mid-Holocene, increased between 5000 and 4000 BP. After $5000 \mathrm{BP}$, soils were partially truncated, whereas small ponds and swampy areas of floodplains desiccated (Zárate et al., 2000). Sandy loess accumulation started at ca. 4600 BP in the Tandilia range (Muhs and Zárate, 2001). Our results agree with these tendencies towards more arid and 
variable conditions since $\sim 4500 \mathrm{yr}$ cal BP. This implied that the highly turbid, deep Sc1 lake (Unit 1) prior to $4500 \mathrm{yr}$ cal BP shifted to a shallower Sc2/Sc3 lake (Unit 2). This extended dry phase of extreme climate variability and recurrent shifts between Sc2 and Sc3 lasted more than two millennia, and persisted until $2000 \mathrm{yr}$ cal BP. A greater climatic variability during the late Holocene was also pointed out by Quattrocchio et al. (2008). According to Vilanova et al. (2010), unstable and variable conditions determined cyclic alternation between dry and wet phases, which in term influence vegetation and lake levels up to $3700 \mathrm{yr}$ cal BP. Tonello and Prieto (2010) pointed out a shift towards more humid conditions since $2000 \mathrm{yr}$ cal BP, in coincidence with the shift to a turbid Sc1 state and high lake levels in Lake La Brava (Unit 3). Frequent fresh water and humid pulses between 1200-670 BP have been also recognized in some shallow pampean lakes (Stutz et al., 2012). Tonello and Prieto (2010) recognized semiarid conditions for the last 500 years. In Lake La Brava, drier conditions are recognized since $215 \mathrm{yr}$ cal BP, coeval with the Little Ice Age recorded in other Pampas' records (i.e., Laprida et al., 2009). A more recent and localized episode of eolian redeposition in the Tandilia range occurred after the Spanish arrival in the $16^{\text {th }}$ century (Zárate and Flegenheimer, 1991).

\section{CONCLUSIONS}

Multiproxy analysis of sediment core $\mathrm{LBr}-4$ from Lake La Brava provides valuable information on natural evolution of the southeastern Pampas in the last 4700 year. Climatic changes seem to have had a significant impact on lake ecology and hydrology, and on crucial in-lake processes defining its trophic state. Cyclic shifts between clear and turbid states occurred since the mid-late Holocene forced by climatic drivers, the turbid regimes predominating during highest and lowest lake levels and droughts.

The following sequence can be drawn:

- High lake-level and turbid states predominated between 4700-4500 yr cal BP. Higher lake levels occurred between $\sim 4700-4600 \mathrm{yr}$ cal BP.

- Moisture balance and precipitation decreased between $\sim 4500-2000$ yr cal BP, determining a lake level drop and a shift to a clear state. This interval was punctuated by two drier episodes: a short interval between 4200-4000 yr cal BP and a second, more extended period between $\sim 3400-2650$ BP. During these episodes, a shift to an inorganic, turbid state occurred.

- A lake level rise and higher productivity between $\sim 2000$ and 250 yr cal BP imply a return to wetter conditions. Lake was deep enough to push the system to a turbid state. This interval was punctuated by a drier episode between 1570-1450 yr cal BP pushing the system to a clear state.

- An abrupt environmental change took place at 200 yr cal BP. Low lake level indicates cold, windy and dry climate associated with the Little Ice Age. These conditions pushed the system to a turbid state.

- The last $\sim 60$ years represents the modern conditions of the lake. Increasing erosion is associated with humid conditions and with human-induced geomorphic modification of the catchment of Lake La Brava.

\section{ACKNOWLEDGMENTS}

We thank to Dr Juan Manuel Lirio and Lic Mario Núñez (Instituto Antártico Argentino) for field support. Nora Irene Maidana (Departamento de Biodiversidad y Biología Experimental, Facultad de Ciencias Exactas y Naturales, Universidad de Buenos Aires, Argentina) help with diatom identification. Financial support was provided by PIP-CONICET 1265/08, PIP-CONICET 2142001100 100014, UBACyT 20020110100153 and CICYT project EROMED (CGL2011-25486). We thank the editor and two anonymous reviewers for their constructive comments, which helped us to improve the manuscript. This is the IDEAN contribution number R-112.

\section{REFERENCES}

Arens P, 1969. [Algunos paisajes geoquímicos de la región pampeana].[Article in Spanish]. Reunión Argentina de la Ciencia del Suelo, Santa Fe, Argentina, Actas 5:107-115.

Barrucand MG, Vargas WM, Rusticucci MM, 2007. Dry conditions over Argentina and the related monthly circulation patterns. Meteorol. Atmos. Phys. 98: 99-114.

Belmecheri S, Namiotko T, Robert C, von Grafenstein U, Danielopol DL, 2009. Climate controlled ostracod preservation in Lake Ohrid (Albania, Macedonia). Palaeogeogr. Palaeocl. 277:236-245.

Borel, CM, Guerstein GR, Prieto AR, 2003. [Palinomorfos acuáticos (algas y acritarcos) del Holoceno de la Laguna Hinojales (Buenos Aires, Argentina): interpretación paleoecológica].[Article in Spanish]. Ameghiniana 40:531-544.

Bronk Ramsey C, 2001. Development of the radiocarbon calibration program OxCal. Radiocarbon 43:355-363.

Bronk Ramsey C, 2008. Radiocarbon dating: revolutions in understanding. Archaeometry 50:249-275.

Camilión M C, 1993. Clay mineral composition of pampean loess (Argentina). Quarter. Int. 17:27-31.

Canavan RW, Slomp CP, Jourabchi P, Van Cappellen P, Laverman AM, Van den Berg GA, 2006. Organic matter mineralization in sediment of a coastal freshwater lake and response to salinization. Geochim Cosmochim Ac. 70:2836-2855.

Cohen AS, 2003. Paleolimnology: the history and evolution of lake systems. Oxford University Press: 528 pp.

Cordini IR, 1942. [Laguna La Brava. Contribución a su conocimiento limnológico].[Thesis in Spanish]. University of Buenos Aires.

Dangavs N, 2005a. [Los ambientes acuáticos de la provincia de Buenos Aires, p. 219-236].[Article in Spanish]. In: R. de Barrio, R. Etcheverry, M. Caballé and E. Llambías (eds.) Proc. XVI Congr. Geol. Argent.

Dangavs N, 2005b. [Los depósitos de yeso intrasedimentario de las lagunas encadenadas de Chascomús, provincia de 
Buenos Aires, p. 141-148].[Article in Spanish]. In: R. de Barrio, R. Etcheverry, M. Caballé and E. Llambías (eds.). Proc. XVI Congr. Geol. Argent.

Dawdy DR, Matalas NC, 1964. Statistical and probability analysis of hydrologic data, part III: analysis of variance, covariance and time series, p. 8-68. In: V. Chow (ed.), Handbook of applied hydrology: a compendium of water-resources technology. McGraw-Hill.

Dustin NM, Wilkinson BH, Owen RM, 1986. Littlefield Lake, Michigan: carbonate budget of Holocene sedimentation in a temperate-region lacustrine system. Limnol. Oceanogr. 31:1301-1311.

Fontana SL, 2005. Holocene vegetation history and palaeoenvironmental conditions on the temperate Atlantic coast of Argentina, as inferred from multi-proxy lacustrine record. J. Paleolimnol. 34:445-469.

Gabellone NA, Solari LC, Claps MC, 2001. Planktonic and physico-chemical dynamics of a markedly fluctuating backwater pond associated with a lowland river (Salado River, Buenos Aires, Argentina). Lakes Reserv. Res. Manage. 6:133-142.

Garibotti EJ, Cervellini PM, Píccolo M, 2009. [Microcrustáceos planctónicos y características limnológicas de dos lagunas pampeanas (Buenos Aires, Argentina)].[Article in Spanish]. Limnetica 28:91-104.

Garreaud RD, Vuille M, Compagnucci R, Marengo J, 2009. Present-day South American climate. Palaeogeogr. Palaeocl. 281:180-195.

González Sagrario MA, Balseiro EG, Ituarte RB, Spivak ED, 2009. Macrophytes as refuge or risky area for zooplankton: a balance set by littoral predacious macroinvertebrates. Freshwater Biol. 54:1042-1053.

Hammer O, Harper DTA, Ryan PD, 2001. Past: paleontological statistics software package for education and data analysis. Paleontol. Electronica 4:1-9.

Irurzún MA, Gogorza CSG, Sinito, AM, Chaparro MAE, Prieto AR, Laprida C, Lirio JM, Navas AM, Nuñez H, (2013). A high-resolution palaeoclimate record for the last $4800 \mathrm{cal}$. years BP on lake La Brava, SE Pampas plains, Argentina. Geofis. Int. (in press).

Izaguirre I, Vinocur A, 1994. Algal assemblages from shallow lakes of the Salado River Basin (Argentina). Hydrobiologia 289:57-64.

Kruse E, 1987. [El agua subterránea en el régimen hidrológico de Laguna la Brava. Informe 40. Programa Prioritario de Asesoramiento a Municipalidades].[Article in Spanish]. Comisión de Investigaciones Científicas. CIC Provincia de Buenos Aires: 18 pp.

Labraga JC, Scian B, Frumento O, 2002. Anomalies in the atmospheric circulation associated with the rainfall excess or deficit in the Pampa Region in Argentina. J. Geophys. Res. 107:46-66.

Laprida C, 2006. [Ostrácodos recientes de la llanura pampeana, Buenos Aires, Argentina: ecología e implicancias paleolimnológicas].[Article in Spanish]. Ameghiniana 43:181-204.

Laprida C, Orgeira MJ, García Chapori N, 2009. [El registro de la Pequeña Edad de Hielo en lagunas pampeanas].[Article in Spanish]. Rev. Asoc. Geo. Argent. 65:603-611.

Laprida C, Valero Garcés B, 2009. [Cambios ambientales de épocas históricas en la pampa bonaerense en base a ostrá- codos: historia hidrológica de la laguna de Chascomús].[Article in Spanish]. Ameghiniana 46:95-111.

Lirio JM, Núñez HJ, Chaparro MA, Sinito AM, Irurzún A, Gogorza CS, 2007. [Laguna La Brava, Provincia de Buenos Aires. Relaciones paleoclimáticas con Patagonia y Antártida].[Article in Spanish]. Proc. VI Simposio Argentino y III Latinoamericano sobre Investigaciones Antárticas, Buenos Aires. Available from: http://www.dna.gov.ar/CIENCIA/SANTAR07/CD/PDF/GEOR E820.PDF

Masiokas MH, Luckman BH, Villalba R, Delgado S, Skvarca P, Ripalta A, 2009. Little Ice Age fluctuations of small glaciers in the Monte Fitz Roy and Lago del Desierto areas, south Patagonian Andes, Argentina. Palaeogeogr. Palaeocl. 281:351-362.

Masiokas MH, Villalba R, Luckman BH, Mauget S, 2010. Intrato multidecadal variations of snowpack and streamflow records in the Andes of Chile and Argentina between $30^{\circ}$ and $37^{\circ} \mathrm{S}$. J. Hydrometeorology 11:822-831.

McCormac FG, Hogg AG, Blackwell PG, Buck CE, Higham TF, Reimer PJ, 2004. SHCal04 southern hemisphere calibration, 0-11.0 cal kyr BP. Radiocarbon 46:1087-1092.

Muhs DR, Zárate M, 2001. Late Quaternary eolian records of the Americas and their paleoclimatic significance, pp. 183216. In: V. Markgraff (ed.), Interhemispheric climate linkages. Academic Press.

Müller B, Wang Y, Dittrich M, Wehrli B, 2003. Influence of organic carbon decomposition on calcite dissolution in surficial sediments of a freshwater lake. Water Res. 37:524-4532.

Mullins HT, 1998. Holocene lake level and climate change inferred from marl stratigraphy of the Cayuga Lake basin, New York. J. Sediment. Res. 68:569-578.

O'Farrell I, de Tezanos Pinto P, Rodríguez PL, Chaparro G, Pizarro HN, 2009. Experimental evidence of the dynamic effect of free-floating plants on phytoplankton ecology. Freshwater Biol. 54:363-375.

O'Farrell I, Izaguirre I, Chaparro G, Unrein F, Sinistro R, Pizarro H, Rodríguez P, de Tezanos Pinto P, Lombardo R, Tell G, 2011. Water levels as the main driver of the alternation between a free-floating plant and a phytoplankton dominated state: A long-term study in a floodplain lake. Aquat. Sci. 73:275-287.

Penalba OC, Bettolli ML, 2011. Climate change impacts on atmospheric circulation and daily precipitation in the Argentine Pampas Region, p. 307-419. In: J. Blanco and H. Kheradmand (eds.), Climate change - Geophysical foundations and ecological effects. InTech Publ.

Prieto AR, 1996. Late Quaternary vegetational and climatic changes in the Pampa grassland of Argentina. Quaternary Res. 45:73-88.

Quattrocchio ME, Borromei AM, Deschamps CM, Grill SC, Zavala CA, 2008. Landscape evolution and climate changes in the Late Pleistocene-Holocene, southern Pampa (Argentina): evidence from palynology, mammals and sedimentology. Quatern. Int. 181:123-138.

Quirós R, 1998. Fish effects on trophic relationships in the pelagic zone of lakes. Hydrobiologia 361:101-111.

Quirós R, Rennella AM, Boveri MB, Rosso JJ, Sosnovsky A, 2002. [Factores que afectan la estructura y el funcionamiento de las lagunas pampeanas].[Article in Spanish]. Ecología Austral. 12:175-185.

Quirós R, 2004. [Sobre la morfología de las lagunas pam- 
peanas].[Article in Spanish]. Departamento de Producción Animal, Facultad de Agronomía, Universidad de Buenos Aires. Documento No. 3: 16 pp.

Quirós R, Boveri MB, Petracchi CA, Rennella AM, Rosso JJ, Sosnovsky A, Von Bernard HT, 2006. [Los efectos de la agriculturización del humedal pampeano sobre la eutrofización de sus lagunas, p.1-16]. In: J.G. Tundizi, T. Matsumura-Tundisi and C. Sidagis Galli (eds.) [Eutrofização na América do Sul: causas, conseqüèncias e tecnologias de gerenciamento e controle].[Book in Portuguese]. Instituto Internacional de Ecologia.

Ramón Mercau J, Plastani MS, Laprida C, 2014. A review of the genus Limnocythere (Podocopida: Limnocytheridae) in the Pampean region (Argentina), with the description of a new species, Limnocythere cusminskyae sp. nov. Zootaxa 3821:26-36.

Romanelli A, Quiroz Londoño OM, Massone HE, Escalante AH, 2010a. [Validación y ajuste del modelo hidrogeológico conceptual de un humedal de la Llanura Pampeana, Provincia de Buenos Aires, Argentina].[Article in Spanish]. Limnetica 29:407-418.

Romanelli A, Quiroz Londoño OM, Massone HE, Martínez DE, Bocanegra E, 2010b. [El agua subterránea en el funcionamiento hidrológico de los humedales del sudeste bonaerense, Provincia de Buenos Aires, Argentina].[Article in Spanish]. Boletín Geológico Minero 121:373-386.

Romanelli A, Massone, Qutrozl OM, 2011. Integrated hydrogeological study of surface \& ground water resources in the southeastern Buenos Aires Province, Argentina. Int. J. Environ. Res. 5:1053-1064.

Sala JM, 1975. [Recursos hídricos, especial mención de las aguas subterráneas, p. 169-193].[Article in Spanish]. Proc. VI Congr. Geol. Argentina.

Scheffer M, Hosper SH, Meijera M-L, Moss B, Jeppesen E, 1993. Alternative equilibria in shallow lakes. Ecol. Evol. 8:275-279.

Scheffer M, Carpenter SR, 2003. Catastrophic regime shifts in ecosystems: linking theory to observation. Ecol. Evol. 18:648-656.

Scheffer M, 2004. Ecology of shallow lakes. Population and community biology series. 22. Kluwer: 357 pp.

Scheffer M, van Nes EH, 2007. Shallow lakes theory revisited: various alternative regimes driven by climate, nutrients, depth and lake size. Hydrobiologia 584:455-466.

Scian B, Labraga JC, Reimers W, Frumento O, 2006. Characteristics of large-scale atmospheric circulation related to extreme monthly rainfall anomalies in the Pampa Region, Argentina, under non-ENSO conditions. Theor. Appl. Climatol. 85:89-106.

Shapley MD, Ito E, Donovan JJ, 2005. Authigenic calcium carbonate flux in groundwater-controlled lakes: implications for lacustrine paleoclimate records. Geochim. Cosmochim. Ac. 69:2517-2533.

Sosnovsky A, Quirós R, 2006. [El estado trófico de pequeñas lagunas pampeanas, su relación con la hidrología y el uso de la tierra].[Article in Spanish]. Ecologia Austral. 16:115-124.

Sosnovsky A, Rosso JJ, Quirós R, 2010. Trophic interactions in shallow lakes of the Pampa plain (Argentina) and their effects on water transparency during two cold seasons of contrasting fish abundance. Limnetica 29: 233-246.
Stutz S, Prieto AR, Isla FI, 2002. [Historia de la vegetación del Holoceno de la laguna Los Hinojales, sudeste de la provincia de Buenos Aires].[Article in Spanish]. Ameghiniana 39:85-94.

Stutz S, Prieto AR, Isla FI, 2006. Holocene evolution of the Mar Chiquita coastal lagoon area (Argentina) indicated by pollen analysis. J. Quaternary Sci. 21:17-28.

Stutz S, Borel CM, Fontana SL, del Puerto L, Inda H, GarcíaRodríguez F, Tonello MS, 2010. Late Holocene climate and environments of the SE Pampa grasslands, Argentina, inferred from biological indicators in shallow, freshwater Lake Nahuel Rucá. J. Paleolimnol. 44:761-775.

Stutz S, Borel CM, Fontana SL, Tonello MS, 2012. Holocene changes in trophic states of shallow lakes from the Pampa plain of Argentina. Holocene 22:1263-1270.

Tapia A, 1937. [Las cavernas de Ojo de Agua y Las Hachas: historia geológica de la región de La Brava en relación con la existencia del hombre prehistórico].[Article in Spanish]. Dirección de Minería y Geología, Ministerio de Agricultura de la Nación, Buenos Aires, Boletín 43:1-22.

Tietze E, De Francesco CG, 2010. Environmental significance of freshwater mollusks in the Southern Pampas, Argentina: to what detail can local environments be inferred from mollusk composition? Hydrobiologia 641:133-143.

Tietze E, De Francesco CG, 2012. Compositional fidelity of subfossil mollusk assemblages in streams and lakes of the southeastern pampas, Argentina. Palaios 27:401-413.

Tonello MS, Prieto AR, 2010. [Tendencias climáticas para los pastizales pampeanos durante el Pleistoceno tardío-Holoceno: estimaciones cuantitativas basadas en secuencias polínicas fósiles].[Article in Spanish]. Ameghiniana 47:501-514.

van Nes EH, Scheffer M, Van den Berg MS, Coops H, 2002. Dominance of charophytes in eutrophic shallow lakes- when should we expect it to be an alternative stable state? Aquat. Bot. 72:275-96.

van Nes EH, Rip WJ, Scheffer M, 2007. A theory for cyclic shifts between alternative states in shallow lakes. Ecosystems 10:17-27.

Vilanova I, Prieto AR, Stutz S, Bettis EA, 2010. Holocene vegetation changes along the southeastern coast of the argentinean Pampa grasslands in relation to sea-level fluctuations and climatic variability: palynological analysis of alluvial sequences from Arroyo Claromecó. Palaeogeogr. Palaeocl. 298:210-223.

Wagner B, Lotter AF, Nowaczyk N, Reed JM, Schwalb A, Sulpizio R, Varushka V, Wessels M, Zanchetta G, 2009. A 40,000-year record of environmental change from ancient Lake Ohrid (Albania and Macedonia). J. Paleolimnol. 41:407-430.

Wittkop CA, Teranes JL, Dean WE, Guilderson TP, 2009. A lacustrine carbonate record of Holocene seasonality and climate. Geology 37:695-698.

Zárate M, 1997. Late Pleistocene geoarchaeology of the Southern Pampas, Buenos Aires Province, Argentina. Anthropologie 35:197-205.

Zárate M, Flegenheimer N, 1991. Geoarchaeology of the Cerro La China locality (Buenos Aires, Argentina): site 2 and site 3. Geoarchaeology 6:273-294.

Zárate M, Kemp RA, Espinosa M, Ferrero L, 2000. Pedosedimentary and palaeoenvironmental significance of a Holocene alluvial sequence in the southern Pampas, Argentina. Holocene 10:481-488. 